\title{
WOJCIECH GASPARSKI
}

Leon Koźmiński University, Warsaw Institute of Philosophy and Sociology of the Polish Academy of Science wgaspars@kozminski.edu.pl

\section{THE UNIVERSITY'S $70^{\text {th }}$ ANNIVERSARY}

The University's $70^{\text {th }}$ anniversary is the second $70^{\text {th }}$ anniversary celebrated by the City of Łódź. The first celebration took place in 1936, when Kazimierz Twardowski, founder of the Lvov-Warsaw School, turned 70 on 2 October. It was then that Tadeusz Kotarbiński - who later became the rector of the University of Łódź - published an article about his mentor in issue 21(138) of the Pion journal. The article was connected with Kazimierz Twardowski receiving the City of Łódź Prize for his scientific work. ${ }^{1}$ The coincidence of these two anniversaries provokes reflection.

In his laudation of the man who wrote On the Dignity of the University, Tadeusz Kotarbiński wrote about Twardowski's research and about how he organized the work of the philosopher community - in other words he wrote about what he had learnt from his mentor. After all, it was precisely that heritage which he had built on when he taught what he called "small" philosophy at the University of Warsaw before World War II and when he headed the University of Łódź in the first years after the war.

What, then, was the "core of Prof. Twardowski's academic production" [op. cit., 89]? In terms of research method, it was a theory of representation (i.e. ideas and notions). Twardowski's pioneering role was based on indicating that "the professional role of philosophers involves, as an important part, giving the meaning of words .... a definite and distinct shape" [op. cit., 893]. This is especially important when studying the correctness of theorems and justifications. It was also a critique of a "dilettante epistemology" related to the relativism of regarding a sentence as true or false depending on who utters it ("subjective fantasizing"). Another of his achievements was formulating rational and refined opinions on the subject, method and tasks of psychology, or, more precisely, the philosophy of psychology, especially of thinking. The fourth part of Twardowski's output was concerned with ethics. Twardowski found

1 KOTARBIŃSKI T. [1958], "Kazimierz Twardowski”, [in:] Wybór pism, vol. II, Myśli o myśleniu, PWN, Warszawa, pp. 891-899. 
- Kotarbiński writes - "our domestic philosophy to be in a suspicious condition" and made it so "that among the intelligentsia of Lvov ... philosophy at the university gained the reputation of something like daily bread" [op. cit., 896]. "Above all, this was an excellent introductory course for anyone who was to teach anyone anything in future" [op. cit., 897]. It was philosophizing without "any kind of '-ism', no prophesying, no extravagance of inspired individuality ..., nor any pretending to be a genius" [ibid.].

To the question of what inclined Twardowski, a graduate of the University of Vienna, a student of Franz Brentano, to adopt such a programme of activity, Tadeusz Kotarbiński offers this reply:

Finding fallow land in Poland, overgrown with weeds, he rolled up his sleeves and began tearing out the weeds and planting nourishing vegetables. This great, wise and incredibly hard-working teacher made it his mission to teach ne'er-do-well Poles how to work just like Germans can work. In the area, of course, which was available to him. It was mainly a question of character. Twardowski was deeply hurt by the Poles' reputation: Die Polen sind ja so unzuverlassig! Unreliable! It's hard to depend on us! What's worse, the criticism hit the nail on the head ... So this Man, devoted to Poland but brought up in German solidity, undertook a certain, so to speak, Kulturkampf at home... And began eradicating short-lived zeal, tardiness, unreliability in deals, disorderliness, the pursuit of what is currently the most engrossing thing; he made people get down to hard work, respect organizational relations, practise various skills, write detailed papers, offer objective summaries... Oh how grateful they are today, his students of old, to their beloved Mentor for all this! With what great faith they pass those elements that he instilled in them on to their own students! [op. cit., 897].

Nine years passed after these words were written, difficult years dominated by the tragedy of war and the hecatomb of Warsaw, until in 1945 Twardowski's student arrived to create such a university in Łódź that would have the proper dignity. How did he do it? He made good use of Twardowski's programme and his own experience supported by the framework of his consistently developing philosophy of practicality. ${ }^{2}$ Allow me to remind you what I have written about this. ${ }^{3}$

Tadeusz Kotarbiński treated action as a skill of which the analysis and the critique of its notions and methods required studying the language reflecting that skill. One could say with certain emphasis that Kotarbiński raised action to the rank of how philosophy analyses and critiques scientific notions and methods. Focusing on action, Kotarbiński brought science - exact science, to be precise - down from Olympus and into workshops and laboratories where scientific

\footnotetext{
${ }^{2}$ GASPARSKI W. [1993], A Philosophy of Practicality: A Treatise on the Philosophy of Tadeusz Kotarbiński, Societas Philosophica Fennica, Helsinki.

${ }^{3}$ GASPARSKI W. [2006], "Wielkość małej filozofii", [in:] R. Banajski, W. Gasparski and A. Lewicka-Strzałecka, [eds], Myśl Tadeusza Kotarbińskiego i jej współczesna recepcja, Polska Akademia Nauk i Towarzystwo Naukowe Prakseologii, Warszawa, pp. 13-19.
} 
research, ergo actions, are performed. This consideration, first and foremost, forms the foundation of Tadeusz Kotarbiński's philosophical system. In order to answer the question of what system we are speaking of, we need to consider the following. Firstly, the works of Tadeusz Kotarbiński should be treated as a whole, i.e. as a philosophical system. Secondly, Kotarbiński's method of building this system consisted in analysing the language of the disciplines whose methodological criticism he performed. Thirdly, Kotarbiński's philosophy should be understood in the same way that he understood philosophy and demanded it should be understood, i.e. as the science of science. Fourthly and finally, science, or scientific disciplines to be more precise, should be understood in the way adopted by Kotarbiński, i.e. as a separate field deserving to be the subject of intellectual university teaching. The atomic level of Tadeusz Kotarbiński's philosophical system is a universe of behaviours of a subject creatively changing the encountered reality, this subject being "a body living, awake and aware" and the reality being "a tangle of interdependent and changing things", as Kotarbiński put it. ${ }^{4}$ This universe is the world of the practical activity of humans as acting subjects. Tadeusz Kotarbiński's philosophical system is the effect of reflecting on this world, so it is exactly a philosophy of practicality.

Kotarbiński ended his article about Kazimierz Twardowski with the words: "And we can guess how touched the Professor will be that the thanks come from Łódź itself! The city from the very heart of the Congress Kingdom thanks a citizen of Lvov, a city of practical people thanks a coryphaeus of philosophical culture. In this is contained a symbolism of extensive and deep relations so dear to our Mentor's heart..." [op. cit., 899].

The obvious thing to do today, on the $70^{\text {th }}$ anniversary of the University of Łódź, is to offer similar words about Tadeusz Kotarbiński, its first rector:

We can guess that Łódź of all places is certainly grateful to him! A city from the very heart of Poland thanks a native of Warsaw from the Lvov-Warsaw school, a city of practical people thanks a philosopher of practicality, a coryphaeus of philosophical culture and courage in action, i.e. efficacy in achieving worthy goals. In this is contained a symbolism of extensive and deep relations so dear to our Mentor's heart.

Please accept my respect and wishes for a rewarding debate.

\footnotetext{
${ }^{4}$ KOTARBIŃSKI T. [1993], Ontologia, teoria poznania i metodologia nauk, Dzieła wszystkie, Ossolineum, Wrocław, pp. 175-176.

5 GASPARSKI W. [1991], "Filozofia Tadeusza Kotarbińskiego filozofią praktyczności”, [in:] W. Gasparski, A. Strzałecki, [eds], Logika, praktyka, etyka: Przesłania filozofii Tadeusza Kotarbińskiego, Towarzystwo Naukowe Prakseologii, Warszawa, p. 31.
} 